\title{
DETERMINATION OF LEAD AND ARSENIC IN TOBACCO AND CIGARETTES: AN IMPORTANT ISSUE OF PUBLIC HEALTH
}

\author{
Konstansa Lazarević1, Dejan Nikolić1, Ljiljana Stošić1, Suzana Milutinović1, Jelena Videnović1, Dragan \\ Bogdanović ${ }^{1,2}$ \\ ${ }^{1}$ Public Health Institute Niš, Serbia \\ ${ }^{2}$ State University, Novi Pazar, Serbia
}

\section{SUMMARY}

Contents of lead and arsenic were determined in 617 tobacco samples and 80 samples of cigarettes. The mean content of lead in tobacco was $0.93 \mu \mathrm{g} / \mathrm{g}$ (range $0.02-8.56 \mu \mathrm{g} / \mathrm{g}$ ) and arsenic was $0.15 \mu \mathrm{g} / \mathrm{g}$ (range $<0.02-2.04 \mu \mathrm{g} / \mathrm{g}$ ). The mean content of lead in cigarettes was $1.26 \mu \mathrm{g} / \mathrm{g}$ (range $0.02-6.72 \mu \mathrm{g} / \mathrm{g}$ ) and arsenic was $0.11 \mu \mathrm{g} / \mathrm{g}$ (range $<0.02-0.71 \mu \mathrm{g} / \mathrm{g}$ ). There was a large variability in lead and arsenic content among samples of tobacco and samples of cigarettes. Positive correlation between lead and arsenic contents in tobacco was found $(r=0.22 ; p<0.0001)$.

Based on our data and data from literature we compare the content of lead and arsenic in tobacco and cigarettes in other studies and discuss the influence of smoking to lead and arsenic exposure and health.

In conclusion, at the same time with the implementation of tobacco use prevention programmes it is advisable to implement continuous monitoring of lead and arsenic in tobacco and cigarettes in order to reduce the health risk due to exposure of these metals.

Key words: tobacco, cigarette, lead, arsenic

Address for correspondence: K. Lazarević, Public Health Institute Niš, Dr Z Đinđica 50, 18000 Niš, Serbia. E- mail: koni33@hotmail.com

\section{INTRODUCTION}

According to the data of WHO - in the 20th century, 100 million people have died from tobacco use (1). At the same time, studies were focused on quantitative and qualitative analyses of tobacco constituents potentially responsible for the negative health effects.

More than 4,000 chemicals have been isolated from tobacco (hydrocarbons, aldehydes, ketones, aromatic hydrocarbons, heavy metals including lead and arsenic). Lead and arsenic have been identified and measured both in tobacco and tobacco smoke (2-6).

It is observed that contents of lead (7-9) and arsenic (10-12) in biological samples of human population are much higher in smokers than those in non-smokers.

Lead and arsenic are classified as carcinogenic to humans or possibly carcinogenic to humans (group 1 or 2) (13), but also various other negative effects of lead and arsenic on human health have been recognized (14).

Human population is exposed to lead and arsenic from many sources (air, water, soils, foodstuffs, and anthropogenic sources) (6). Smoking is not the main source of lead and arsenic exposure for humans, but cigarette smoking influences lead and arsenic toxicity.

Arsenic is methylated and eliminated from the body by urine. Cigarette smoking lowers methylation capacity of arsenic (15) and elimination of arsenic from the body. Cigarette smoking also can act synergistically with arsenic exposure to cause DNA damage in lungs (16). Mortality risk from heart disease, skin lesion, bladder cancer, and lung cancer associated with exposure to arsenic is higher among smokers (17-20).
Lead circulates in the bloodstream and accumulates in tissues and bones, or is eliminated from the body, primarily in urine. The blood brain barrier of children and infants is relatively impermeable to lead but they are at high risk of accumulating lead in the brain and central nervous system which may cause neurodegeneration (21). Tobacco is an important source of lead in secondhand tobacco smokers (children and adolescents) in the United States. Blood levels of lead were $14 \%$ and $24 \%$ higher in children who lived with 1 or with 2 or more smokers than in children living with non-smokers (22).

Lead plays a significant role in tobacco toxicity, especially radioactive $210 \mathrm{~Pb} .210 \mathrm{~Pb}$ is a product of $238 \mathrm{U}$ disintegration and its existence in tobacco depends on the tobacco origin and natural level of uranium in the soil where tobacco grows. In Italy, $210 \mathrm{~Pb}$ dose from inhalation of cigarette smoke is much higher than the dose from ambient air (23).

Exposure to metals through tobacco depends on the amount of metal present in tobacco, a percentage that is transferred to the tobacco smoke and the percentage that is absorbed.

The aim of this paper is to present content of lead and arsenic in tobacco and cigarettes analysed in the Institute for Public Health Niš (Serbia), and data from studies around the world available.

\section{MATERIALS AND METHODS}

In the period from 2008-2010, the accredited laboratory (ISO 17025) in the Public Health Institute Niš, determined the content of lead and arsenic in 617 samples of imported tobacco and 60 samples 
of imported cigarettes. The origins of analysed tobacco samples (Virginia, Burley, and Oriental tobacco types) was from different production areas around the world (Europe, Asia, America, and Africa). For the purposes of this investigation, 20 samples of different brands of cigarettes were purchased from the Niš (Serbia) market. Brand names are not discussed in this paper due to legal restrictions.

Usually, cigarette is made up of tobacco, paper and additives. For this reason, 19 samples of aroma and 5 samples of paper also were analysed by standard methods.

Samples were prepared before measurement by Electrothermal Atomic Absorption Spectrometry, instrument: Perkin Elmer AnAnalyst 600, with transversely-heated graphite atomizer (THGA) system, with Zeeman background correction.

$10 \mathrm{~g}$ homogenized sample and $10 \mathrm{ml}$ of magnesium nitrate solution (10\% w/v in 95\% ethanol) was mixed well in $100 \mathrm{ml}$ beaker and evaporated on a steam bath and completly dried in oven for $1 \mathrm{hr}$ at $150^{\circ} \mathrm{C}$. Samples are heated on a hot plate $\left(200^{\circ} \mathrm{C}\right)$, gradually increasing temperature until organic matter was thoroughly charred (not exceeding $450^{\circ} \mathrm{C}$ ). Beakers were placed in a muffle furnace and turned into ash overnight at $450^{\circ} \mathrm{C}$. In removed and cooled beakers, a few drops of $\mathrm{HNO}_{3}$ were added, dried on a hot plate, returned to muffle furnace for $1 \mathrm{~h}$ until they turned into white ash, repeating the nitric acid treatment if necessary. Beaker was cooled and $10 \mathrm{ml}$ of extraction acid were added carefully (200 $\mathrm{ml}$ conc. $\mathrm{HCl}+650 \mathrm{ml} \mathrm{H} \mathrm{H}_{2}+150 \mathrm{ml}$ conc. $\mathrm{HNO}_{3}$ ) to dissolve ash (heated if necessary) (24).

Used beakers were soaked in $10 \% \mathrm{HNO}_{3}$ for $24 \mathrm{~h}$; washed with de-ionized water and dried in order to avoid contamination.

All used chemicals were of high purity required for the trace metals analysis: extra pure nitric acid $\left(69 \% \mathrm{HNO}_{3}\right)$, hydrochloric acid $(36 \% \mathrm{HCl})$ (Merck, Darmstadt, Germany), and modifiers $\left(\mathrm{NH}_{2} \mathrm{H}_{2} \mathrm{PO}_{4}, \mathrm{Pd}\left(\mathrm{NO}_{3}\right)_{2}\right.$ and $\mathrm{Mg}\left(\mathrm{NO}_{3}\right)_{2}$, Merck, Darmstadt, Germany).

Samples were routinely analysed in laboratory, in duplicate and as spiked samples as QA/QC measures. The intralaboratory precision and accuracy of the results is controlled for every run starting with a control blank and quality control samples (duplicate and spiked).

This procedure was repeated in series after every fifth or tenth sample. Results vary for lead within $6 \%$ and $12 \%$ for arsenic (CV $\%)$. The results are interpreted according to current legal Book of regulation (24).
Descriptive statistics (mean, standard deviation, median), coefficient of variation (CV\%), and Pearson's coefficient of correlation (r) were processed by Microsoft Excel software.

\section{RESULTS}

Metal concentrations found in tobacco and cigarettes are shown in Table 1 (for lead) and Table 2 (for arsenic).

The Book of the Regulations stipulates maximum permitted levels (MPL) of lead $(10 \mathrm{mg} / \mathrm{kg})$ and arsenic $(3 \mathrm{mg} / \mathrm{kg})$ in tobacco and cigarettes. In all analysed samples of tobacco and cigarettes the concentration of lead and arsenic was within legal limits (Table 1 and 2).

For lead and arsenic in tobacco and cigarette, results showed the high coefficient of variation (CV \%).

Table 3 showed significant positive correlation $(p<0.0001)$ between lead and arsenic content in tobacco but not in cigarettes.

Cigarettes contain tobacco, paper, and additives. Many additives are used in cigarette manufacture as well as paper. They contain heavy metals including lead and arsenic (Table 4 and 5).

Content of lead and arsenic in paper and tobacco was lower than in tobacco and cigarettes.

\section{DISCUSSION}

Metal content in tobacco depends on soil properties, atmospheric conditions, and requirements for tobacco farming (use of pesticide and fertilizer). Tobacco plants take up lead and arsenic from soil and concentrate these metals in leaves. For this reason, there are large variations in the content of metals in tobacco between countries.

In two studies content of lead and arsenic in tobacco and cigarettes from around the world was analysed. Watanabe et al. (25) analysed lead contents in 331 samples of cigarettes from various areas of the world. The mean content of lead was $1.76 \mu \mathrm{g} / \mathrm{g}$ (range $0.46-43.66 \mu \mathrm{g} / \mathrm{g}$ ), and was higher than the lead content in our study $(0.93 \mu \mathrm{g} / \mathrm{g})$. Lugon-Moulin et al. (26) analysed 1,431 leaf samples of tobacco from Africa, Europe, South and North America. Content of arsenic $(0.4 \mu \mathrm{g} / \mathrm{g})$ was higher then arsenic content in tobacco found out in our study $(0.15 \mu \mathrm{g} / \mathrm{g})$.

Table 1. Content $(\mu \mathrm{g} / \mathrm{g})$ of lead in tobacco and cigarettes

\begin{tabular}{|l|c|c|c|c|c|c|c|}
\hline & $\begin{array}{c}\text { Number } \\
\text { of samples }(\mathrm{n})\end{array}$ & Mean & $\begin{array}{c}\text { Standard } \\
\text { deviation }\end{array}$ & CV (\%) & Median & Min-max & $>$ MPL \\
\hline Tobacco & 617 & 0.93 & 1.1 & 118.3 & 0.58 & $0.02-8.56$ & - \\
\hline Cigarette & 80 & 1.26 & 1.7 & 134.9 & 0.53 & $0.02-6.72$ & - \\
\hline
\end{tabular}

Table 2. Content $(\mu \mathrm{g} / \mathrm{g})$ of arsenic in tobacco and cigarettes

\begin{tabular}{|l|c|c|c|c|c|c|c|}
\hline & $\begin{array}{c}\text { Number } \\
\text { of samples }(\mathbf{n})\end{array}$ & Mean & $\begin{array}{c}\text { Standard } \\
\text { deviation }\end{array}$ & CV (\%) & Median & Min-max & $>$ MPL \\
\hline Tobacco & 617 & 0.15 & 0.19 & 126.7 & 0.11 & $<0.02-2.04$ & - \\
\hline Cigarette & 80 & 0.11 & 0.09 & 81.8 & 0.10 & $<0.02-0.71$ & - \\
\hline
\end{tabular}


Table 3. Correlations between lead and arsenic content in analysed samples of tobacco and cigarettes

\begin{tabular}{|l|c|c|}
\hline & $\begin{array}{c}\text { Coefficient of } \\
\text { correlation }(r)\end{array}$ & $\mathbf{p}$ \\
\hline Tobacco & 0.220 & $p<0.0001$ \\
\hline Cigarettes & -0.06 & $p>0.01$ \\
\hline
\end{tabular}

The results of present study showed lower content of lead and arsenic in tobacco and cigarettes than most other studies did and these were within legal limits. There was a large variability in lead and arsenic content among samples because the origin of tobacco and its variety influenced the metal content.

The mean levels of lead determined in cigarettes in our study were lower than those determined in cigarettes from markets in China (27, 28), Nigeria (29), Jordan (30), Pakistan (31), Russia (28), and similar to Korean domestic cigarettes (32), and ciga- rettes commonly smoked in India, Germany, and Canada (28). Our results for lead content in cigarettes were higher than those observed in Poland (7), Brazil (33), and cigarettes imported to Korea from UK (32) (Table 6).

Compared to the values described in the literature for arsenic in cigarettes (Table 7), the mean levels of arsenic in the present study were lower than those reported in the studies in China (27), and from Korean domestic cigarettes (32), and similar to cigarettes sold in UK (32). Only in one study from Brazil (33) mean content of arsenic was lower compared to that reported in our study (Table 7).

A significant positive correlation was observed between lead and arsenic content in tobacco but not in cigarettes. These results suggest the possibility that these metals in tobacco originated from the same source.

Contents of lead and arsenic in paper and aroma of cigarettes are much lower than in tobacco and do not influence the contents of those metals in cigarettes.

Table 4. Content $(\mu \mathrm{g} / \mathrm{g})$ of lead in additives (aroma) and paper for cigarette

\begin{tabular}{|l|c|c|c|c|c|c|}
\hline & $\begin{array}{c}\text { Number } \\
\text { of samples }(\mathbf{n})\end{array}$ & Mean & $\begin{array}{c}\text { Standard } \\
\text { deviation }\end{array}$ & CV (\%) & Median & Min-max \\
\hline Aroma & 19 & 0.06 & 0.04 & 66.7 & 0.07 & $0.01-0.13$ \\
\hline Paper & 5 & 0.38 & 0.14 & 36.8 & 0.36 & $0.2-0.55$ \\
\hline
\end{tabular}

Table 5. Content $(\mu \mathrm{g} / \mathrm{g})$ of arsenic in additives (aroma) and paper for cigarette

\begin{tabular}{|l|c|c|c|c|c|c|}
\hline & $\begin{array}{c}\text { Number } \\
\text { of samples }(\mathbf{n})\end{array}$ & Mean & $\begin{array}{c}\text { Standard } \\
\text { deviation }\end{array}$ & CV $(\%)$ & Median & Min-max \\
\hline Aroma & 19 & 0.023 & 0.01 & 4.3 & 0.02 & $<0.02-0.05$ \\
\hline Paper & 5 & 0.05 & 0.03 & 60 & 0.05 & $<0.02-0.08$ \\
\hline
\end{tabular}

Table 6. Comparison between the present result and available reported content of lead in cigarettes

\begin{tabular}{|c|c|c|c|}
\hline Source of cigarettes & $\begin{array}{l}\text { Mean } \\
(\mu \mathrm{g} / \mathrm{g})\end{array}$ & $\begin{array}{l}\text { Range } \\
(\mu \mathrm{g} / \mathrm{g})\end{array}$ & Reference \\
\hline Cigarettes sold in China & 2.65 & $1.2-6.5$ & O'Connors et al. (27) \\
\hline Cigarettes sold in Nigeria & 10.8 & - & Yebpella et al. (29) \\
\hline Cigarette brands sold and/or produced in Jordan & 2.67 & $2.10-3.23$ & Massadeh et al. (30) \\
\hline Domestic cigarettes in Pakistan & 14.39 & $10.16-27.33$ & \multirow{2}{*}{ Ajab et al. (31) } \\
\hline Imported cigarettes in Pakistan & 8.749 & $2.5-14.0$ & \\
\hline Cigarette brands sold in Korea & 1.35 & $0.88-2.13$ & \multirow{2}{*}{ Jung et al. (32) } \\
\hline Cigarette brands sold in UK & 0.74 & $0.45-1.35$ & \\
\hline $\begin{array}{l}\text { Cigarettes commonly smoked in: } \\
\text { China } \\
\text { Canada } \\
\text { India } \\
\text { Germany } \\
\text { Russia }\end{array}$ & $\begin{array}{l}4.48 \\
1.45 \\
1.57 \\
1.62 \\
1.86\end{array}$ & $\begin{array}{l}- \\
- \\
- \\
-\end{array}$ & Müller et al. (28) \\
\hline Cigarettes produced in Poland & 0.7667 & - & Galażyn-Sidorczuk et al. (7) \\
\hline Cigarettes commercialized in Brazil & 0.27 & $0.19-0.39$ & Viana et al. (33) \\
\hline Our study & 1.26 & $0.02-6.72$ & \\
\hline
\end{tabular}


Table 7. Comparison between the present result and available reported content of arsenic in cigarettes

\begin{tabular}{|l|c|c|c|}
\hline Source of cigarettes & $\begin{array}{c}\text { Mean } \\
(\mu \mathrm{g} / \mathrm{g})\end{array}$ & $\begin{array}{c}\text { Range } \\
(\mu \mathrm{g} / \mathrm{g})\end{array}$ & Reference \\
\hline Cigarettes sold in China & 0.82 & $0.3-3.33$ & O'Connors et al. (27) \\
\hline Cigarettes commercialized in Brazil & 0.09 & $0.05-0.13$ & Viana et al. (33) \\
\hline Cigarette brands sold in Korea & 0.23 & $0.17-0.31$ & \multirow{2}{*}{ Jung et al. (32) } \\
\hline Cigarette brands sold in UK & 0.12 & $0.07-0.18$ & \\
\hline Our study & 0.11 & $<0.02-0.71$ & \\
\hline
\end{tabular}

To reduce the risk of human population exposure to lead and arsenic, continuous monitoring of these two metals in tobacco is required as in other countries $(34,35)$ simultaneously with the implementation of tobacco control programmes in Serbia.

\section{REFERENCES}

1. World Health Organization. The World health report 2002: reducing risks, promoting healthy life. Geneva: WHO; 2002.

2. WHO Study Group on Tobacco Product Regulation. Guiding principles for the development of tobacco product research and testing capacity and proposed protocols for the initiation of tobacco product testing [Internet] Geneva: WHO; 2004 [cited 2007 Apr 20]. Available from: http://www. who.int/tobacco/global_interaction/tobreg/goa_2003_principles/en/ index.html.

3. IARC Working Group on the Evaluation of the Carcinogenic Risk of Chemicals to Humans. Tobacco smoking. IARC monographs on the evaluation of the carcinogenic risk of chemicals to humans Vol. 38. Lyon: International Agency for Research on Cancer; 1986.

4. Chang MJ, Walker K, McDaniel RL, Connell CT. Impaction collection and slurry sampling for the determination of arsenic, cadmium, and lead in sidestream cigarette smoke by inductively coupled plasma-mass spectrometry. J Environ Monit. 2005 Dec;7(12):1349-54.

5. Torrence KM, McDaniel RL, Self DA, Chang MJ. Slurry sampling fo the determination of arsenic, cadmium, and lead in mainstream cigarette smoke condensate by graphite furnace-atomic absorption spectrometry and inductively coupled plasma-mass spectrometry. Anal Bioanal Chem. 2002 Mar;372(5-6):723-31.

6. Chiba M, Masironi R. Toxic and trace elements in tobacco and tobacco smoke. Bull World Health Organ. 1992;70(2):269-75.

7. Galazyn-Sidorczuk M, Brzóska MM, Moniuszko-Jakoniuk J. Estimation of Polish cigarettes contamination with cadmium and lead, and exposure to these metals via smoking. Environ Monit Assess. 2008 Feb;137(13):481-93.

8. Afridi HI, Kazi TG, Kazi NG, Jamali MK, Arain MB, Sirajuddin, et al. Evaluation of cadmium, lead, nickel and zinc status in biological samples of smokers and nonsmokers hypertensive patients. J Hum Hypertens. 2010 Jan;24(1):34-43.

9. Babalola OO, Adekunle IM, Okonji RE, Ejim-Eze EE, Terebo O. Selected heavy metals in blood of male Nigerian smokers. Pak J Biol Sci. 2007 Oct 15;10(20):3730-3.

10. Lindberg AL, Goessler W, Gurzau E, Koppova K, Rudnai P, Kumar R, et al. Arsenic exposure in Hungary, Romania and Slovakia. J Environ Monit. 2006 Jan;8(1):203-8.

11. Saad A, Hassanien MA. Assessment of arsenic level in the hair of the nonoccupational Egyptian population: pilot study. Environ Int. 2001 Dec;27(6):471-8.

12. Wolfsperger M, Hauser G, Gössler W, Schlagenhaufen C. Heavy metals in human hair samples from Austria and Italy: influence of sex and smoking habits. Sci Total Environ. 1994 Dec 1;156(3):235-42.

13. International Agency for Research on Cancer (IARC). Agents reviewed by the IARC monographs: volumes 1-100A. Lyon: IARC; 2009.

14. Järup L. Hazards of heavy metal contamination. Br Med Bull 2003;68:167-82.
15. Hopenhayn-Rich C, Biggs ML, Smith AH, Kalman DA, Moore LE. Methylation study of a population environmentally exposed to arsenic in drinking water. Environ Health Perspect. 1996 Jun;104(6):620-8.

16. Hays AM, Srinivasan D, Witten ML, Carter DE, Lantz RC. Arsenic and cigarette smoke synergistically increase DNA oxidation in the lung. Toxicol Pathol. 2006;34(4):396-404.

17. Chen Y, Graziano JH, Parvez F, Liu M, Slavkovich V, Kalra T, et al. Arsenic exposure from drinking water and mortality from cardiovascular disease in Bangladesh: prospective cohort study. BMJ. 2011 May 5;342:d2431. doi: 10.1136/bmj.d2431. PubMed PMID: 21546419; PubMed Central PMCID: PMC3088786.

18. Lindberg AL, Sohel N, Rahman M, Persson LA, Vahter M. Impact of smoking and chewing tobacco on arsenic-induced skin lesions. Environ Health Perspect. 2010 Apr;118(4):533-8.

19. Steinmaus C, Yuan Y, Bates MN, Smith AH. Case-control study of bladder cancer and drinking water arsenic in the western United States. Am J Epidemiol. 2003 Dec 15;158(12):1193-201.

20. Chen CL, Hsu LI, Chiou HY, Hsueh YM, Chen SY, Wu MM, et al.; Blackfoot Disease Study Group. Ingested arsenic, cigarette smoking, and lung cancer risk: a follow-up study in arseniasis-endemic areas in Taiwan. JAMA. 2004 Dec 22;292(24):2984-90.

21. White LD, Cory-Slechta DA, Gilbert ME, Tiffany-Castiglioni E, Zawia $\mathrm{NH}$, Virgolini M, et al. New and evolving concepts in the neurotoxicology of lead. Toxicol Appl Pharmacol. 2007 Nov 15;225(1):1-27.

22. Apostolou A, Garcia-Esquinas E, Fadrowski JJ, McClaine P, Weaver VM, Navas-Acien A. Secondhand Tobacco Smoke: A Source of Lead Exposure in US Children and Adolescents. Am J Public Health. 2011 Aug 25. doi: 10.2105/AJPH.2011.300161. PubMed PMID: 21852639.

23. Desideri D, Meli MA, Feduzi L, Roselli C. 210Po and 210Pb inhalation by cigarette smoking in Italy. Health Phys. 2007 Jan;92(1):58-63.

24. Book of regulation on conditions concerning health safety of consumer goods in trade. Official gazette SFRJ.1983:26. Amendments 1984:61, 1986:56, 1989:50, 1991:18. (In Serbian.)

25. Watanabe T, Kasahara M, Nakatsuka H, Ikeda M. Cadmium and lead contents of cigarettes produced in various areas of the world. Sci Total Environ. 1987 Oct;66:29-37.

26. Lugon-Moulin N, Martin F, Krauss MR, Ramey PB, Rossi L. Arsenic concentration in tobacco leaves: a study on three commercially important tobacco (Nicotiana tabacum L.) types. Water Air Soil Pollut. 2008;192(14):315-9.

27. O'Connor RJ, Li Q, Stephens WE, Hammond D, Elton-Marshall T, Cummings KM, et al. Cigarettes sold in China: design, emissions and metals. Tob Control. 2010 Oct;19 Suppl 2:i47-53.

28. Müller G, Eggersgluess D, Raju NN. Heavy metal $(\mathrm{Cd}, \mathrm{Cu}, \mathrm{Pb}, \mathrm{Cr}, \mathrm{Zn}$, $\mathrm{Hg}$ ) concentrations in tobacco of commonly smoked cigarette brands purchased in Germany, China, Russia, India and Canada. In: Proceedings of the International Conference on Heavy Metals in the Environment; 2000 Aug 6-10; Ann Arbor, Michigan, USA.

29. Yebpella GG, Shallangwa GA, Hammuel C, Tech B. Magomya A, Oladipo MOA, et al. Heavy metal content of different brands of cigarettes commonly smoked in Nigeria and its toxicological implications. Pac J Sci Technol. 2011;12(1):356-62.

30. Massadeh AM, Alali FQ, Jaradat QM. Determination of cadmium and lead in different cigarette brands in Jordan. Environ Monit Assess. 2005 May;104(1-3):163-70.

31. Ajab H, Yasmeen S, Yaqub A, Ajab Z, Junaid M, Siddique M, et al. Evaluation of trace metals in tobacco of local and imported cigarette brands used in Pakistan by spectrophotometer through microwave digestion. J Toxicol Sci. 2008 Oct;33(4):415-20. 
32. Jung MC, Thornton I, Chon HT. Arsenic, cadmium, copper, lead, and zinc concentrations in cigarettes produced in Korea and the United Kingdom. Environ Technol. 1998;19(2):237-41.

33. 33 Viana GF, Garcia KS, Menezes-Filho JA. Assessment of carcinogenic heavy metal levels in Brazilian cigarettes. Environ Monit Assess. 2011 Oct;181(1-4):255-65.

34. Loubeau PR. Selected aspects of tobacco control in Croatia. Cent Eur J Public Health. 2009 Mar; 17(1):47-52.
35. Foley KL, Balázs P. Social will for tobacco control among the Hungarian public health workforce. Cent Eur J Public Health. 2010 Mar;18(1):25-30.

Received October 11, 2011 Accepted in revised form January 21, 2012 